\title{
ENVIRONMENT AND MENTAL HEALTH IN THE PANDEMIC TIME COVID-19 IN IGD NURSE ROYAL PRIMA MEDAN HOSPITAL
}

\author{
Khainir Akbar $^{1 *}$, Sri Lestari Ramadhani Nasution ${ }^{1}$, Ermi Girsang ${ }^{1}$ \\ ${ }^{1}$ Fakultas Kedokteran, Universitas Prima Indonesia, Sumatera Utara, Indonesia \\ * Correspondence email: ermigirsang@unprimdn.ac.id
}

\begin{abstract}
The mental health of health workers during the COVID-19 pandemic period is a present issue that must be given more attention. It is because health workers are the spearhead of handling the COVID19 case, which is increasing daily. The purpose of the research to examine the mental health of IGD nurses at Royal Prima Hospital Medan by using variable demographic characteristics (age, gender, years of service), family environment, social environment, and work environment. This type of research is a quantitative study, with the research sample being all emergency room nurses at Royal Prima Hospital Medan. The data were processed using correlation analysis in SPSS. The results showed that the demographic characteristics, family environment, social environment, and work environment were positively correlated with mental health in IGD nurses at Royal Prima Medan Hospital. Suggestions for further research are to use a larger sample and be able to use other variables according to the theory of Cooper and Davidson.
\end{abstract}

Keywords: Family Environment; Mental Health; Social Environment; Work Environment

\section{INTRODUCTION}

The high number of COVID-19 cases were spreading to nurses, doctors, and other health workers at risk of being exposed to Covid-19. Hospitals that are health service facilities and referrals for handling COVID19 have the highest risk of being exposed to the virus. Medical personnel is the main element as well as the front line in dealing with this virus. A large number of workers, the use of high technology, the continuous frequency of workers, and the freedom of public access to hospitals are characteristics of the hospital, so that this shows the increasingly complex work risk mitigation in Health workers. ${ }^{1}$ Exposure to the risks of hospital work can also reach the community and the surrounding environment. These risks in emergencies such as the COVID19 pandemic show the importance of implementing occupational safety and health for all health service facilities, including hospitals. Occupational Safety and Health, according to the ILO and WHO, is defined as efforts to increase and maintain the highest degree of physical, mental, and social welfare of workers in all jobs. Moreover, the availability of health service facilities and medical equipment is an essential factor in supporting the successful handling of COVID19. In Indonesia, many hospitals are still used as a reference for handling COVID19, which experience limited medical facilities and equipment. The Indonesian Doctors Association (IDI), on June 7, 2020, stated that 32 doctors had died due to COVID19. Meanwhile, according to Lutfia, the number of nurses who died from COVID19 has also reached 20 cases. However, to this day, cases of the death of doctors and other medical personnel are increasing. ${ }^{2}$

From the results of a study by the research team from the Faculty of Medicine, University of Indonesia (MKK FKUI), more than 100 doctors and hundreds of medical personnel died due to contracting COVID-19 while on duty to provide health services to Covid-19 patients. Also, $83 \%$ of health workers in Indonesia experience burnout syndrome, which interferes with work productivity and efficiency because it impacts nurses' quality of life, which has decreased 
because the degree of burnout experienced has led to moderate to severe. The extreme stress experienced by health workers during the pandemic has resulted in many health workers experiencing burnout syndrome. ${ }^{3}$

Working under pressure from the public and the media, which is routine and has a long, long work duration, routine that much medical personnel has not had the chance to experience has a negative psychological impact, including emotional disturbances, depression, mental health disorders, bad mood, irritability, panic, phobias. And symptoms of insomnia. ${ }^{4}$

Wursanto explains that various factors can influence forming attitudes related to the work environment. These factors can be classified into two, consisting of physical and psychological work environments. As internally and externally, according to Wirawan it is also influential, ${ }^{5}$

1. Internal factors namely factors from the health workers. Internal factors are factors that come from birth and are acquired during a period of development. The higher the internal factor in the employee, the better it is for the worker. However, if it is different, health workers' factors are also getting lower so that their performance is also low.

2. Internal environmental factors and the workplace while carrying out their responsibilities require support from where he works. This support includes a strategy, sufficient resources, and an appropriate compensation and management system.

3. External environmental factors of the organization, including conditions, events, and situations outside the environment, affect employee work. ${ }^{6}$

The focus of the location in this study is the Royal Prima Medan Hospital. The Royal Prima Hospital has accommodated hundreds of patients with a positive status of COVID19. The number of COVID19 positive patients in North Sumatra continues to increase and has now exceeded 27,000 cases according to data obtained through the North Sumatra Province
COVID19 Handling Acceleration Task Force. Royal Prima Medan hospital, which is located on Jl. Ayahanda No.68A, Sei Putih Tengah, Kec. Medan Petisah, Medan City, North Sumatera, is one of the largest private hospitals as a reference for COVID19. The case related to COVID19 that was horrendous at the Royal Prima Hospital was the death of one of the patients by jumping from the balcony. This, of course, brought negative impacts and wrong speculations on the hospital. The effect will affect not only other patients but also the hospital workers. Cases like this will easily cause stress for hospital workers, especially nurses who are on duty 24 hours to accompany them. ${ }^{7}$

Based on the background above, the researcher studied the relationship between mental health and family environmental factors, social environment, and work environment in IGD Royal Prima Medan Hospital. $^{8}$

\section{MATERIAL AND METHODS}

This research uses descriptive quantitative research with a knownexperimental study using a cross-sectional study design. The research location is located at the Royal Prima Hospital Medan, Sumatra North start February to March 2021. The study population here is all 35 emergency room nurses at Royal Prima Hospital Medan using saturated sampling, namely the technique of determining the sample if the entire population is the sample. ${ }^{9}$ In this study, the authors used family environment, social environment, work environment, and demography as independent variables and mental health as the dependent variable. The data used are primary data with data collection techniques using a research questionnaire containing instruments to identify demographics, family environment, social environment, work environment, and mental health using the Self Reporting Questionnaire (SRQ) covering 20 question points. The World Health Organization (WHO) developed this 20-question questionnaire as a mental disorder screening tool. ${ }^{10}$ 


\section{RESULTS}

Validity test

The validity test result concludes that the calculated r-value of all indicators in each variable has a Pearson Correlation value in each indicator, including each variable> $r$ table, namely 0.3338 . It can be called if the whole question of each variable is valid. This matter explains if all indicators can construct research variables.

\section{Reliability Test}

Original Reliability testing concludes that the Cronbach Alpha's value of the overall question indicator in each variable is Cronbach Alpha's > 0.60. It can be called if the whole question of each variable is reliable or can be used.

\section{Descriptive Statistical Analysis}

Table 1. Frequency Distribution of Mental Health Variables Eighteen respondents answered mental health symptoms (51.4\%), while 17 people answered no mental health problems $(48.6 \%)$.

\begin{tabular}{lll}
\hline Answer & Frequency & Percentage (\%) \\
\hline Not & 17 & 48.6 \\
Yes & 18 & 51.4 \\
Total & 35 & 100.0 \\
\hline
\end{tabular}

\section{Correlation Analysis}

The Correlation Test for Family Environment Variables with Mental Health shows that the research conducted on emergency room nurses at Royal Prima Hospital obtained a significance level of $0.003<0.05$. It can be said that the hypothesis which states that there is a relationship between family environment variables and mental health variables is accepted obtained a correlation coefficient of 0.488 , which means that the direction of the relationship is positive, it can be assumed that the higher the support from the subject's family environment, the higher the mental health. Vice versa, the lower the support from one's family environment, the lower the mental health. The data analysis results also show that the study's effective contribution is 0.238 (r2) or equivalent to $23.8 \%$, where $r$ is $(0.488)$ 2. This means that the Family Environment variable contributes $23.8 \%$ to mental health. ${ }^{11}$

The result of the Correlation Test of Social Environment Variables with Mental Health shows that the research conducted on emergency room nurses at Royal Prima Hospital obtained a significance level of $0.031<0.05$, it can be said that the hypothesis which states that there is a relationship between mental health variables and social environment variables is accepted. Obtained a correlation coefficient of 0.364 , which means that the direction of the relationship is positive. It can be assumed that the higher the subject's social environment, the higher the mental health. Vice versa, the lower a person's Social Environment, the lower his mental health. The data analysis results also show that the study's effective contribution is 0.132 (r2) or equivalent to $13.2 \%$, where $r$ is $(0.364)$ 2. This means that the Social Environment variable contributes $13.2 \%$ to mental health. ${ }^{12}$

The result of the Correlation Test of Work Environment Variables with Mental Health shows that the research conducted on emergency room nurses at Royal Prima Hospital obtained a significance level of $0.000<0.05$, it can be said that the hypothesis which states that there is a relationship between mental health variables and Work Environment variables is accepted. Obtained a correlation coefficient of 0.706 , which means that the direction of the relationship is positive. It can be assumed that the higher the subject's work environment, the higher the mental health. Vice versa, the lower one's work environment, the lower the mental health. The data analysis results also show that the effective contribution in the study is 0.498 (r2) or equivalent to $49.8 \%$, where $\mathrm{r}$ is (0.706) 2. This means that the Work Environment variable contributes $49.8 \%$ to mental health. ${ }^{13}$

Variable Correlation Test Results Demographics in this right are age, sex, and years of service with mental health shows that the variables age and years of service have a positive correlation with mental health. This 
shows that the higher the age and tenure of work, the higher the respondent's ability to deal with mental health. In addition, the gender variable shows that male respondents have higher mental endurance than female respondents.

\section{DISCUSSION}

\section{Relationship between demographic characteristics and mental health}

In this study, the authors used the variables age, sex, and length of work as variables representing demographic characteristics. The variables of age, sex, and length of work were chosen because researchers believe there is a significant influence on individual characteristics in dealing with the COVID19 problem. Biological research states that the female gender is more prone to stress at work. There is a significant difference in stress levels with gender. Also, younger employees are more prone to stress due to environmental factors. ${ }^{14}$ Previous research from Wenjuan Du stated that the higher the age, education level, condition of the spouse and children, and the higher the household's income, the fewer mental health symptoms are suspected. The test results in this study are in line with Wenjuan's research which states that the higher the age and duration of work, the higher the respondent's ability to overcome existing problems or have stable mental health. The gender factor in this study shows that female nurses tend to be prone to stress or have a low ability to coping with problems so that their mental health is disturbed. ${ }^{15}$

\section{The relationship between the environment family with mental health}

Sutikno's research miny Note that gender, family function, physical health, and the environment are significantly associated with mental health in the elderly. Ifdil examines the influence of family environmental factors, and he states that mental health is positively correlated with productive personalities where productive personalities are formed from the family environment. In this study, the authors used marital status variables, family dynamics, relationships with children, and support from partners as variables representing the family environment variables. The variable above was chosen because it represents the family arena from Cooper and Davidson's theory. ${ }^{16}$ Family environment contributed $23.8 \%$ to mental health in this study and is positively correlated. This means that the more support the family environment has, the better the mental health will be.

\section{The relationship between the social environment and mental health}

The variables of alienation, the quantity of moving, the surrounding environment, and social activities represent the study's social and environmental factors. A study by Murray shows a relationship between social anxiety and depression, were $4 \%$ to $8 \%$ experience depression from their social environment. Krause and Shaw found a relationship between disability and poor social interaction skills. ${ }^{17}$ They claim that poor interpersonal relationships and social support will further exacerbate individuals experiencing mental health stress from their social environment. Wiyono also concluded a concept which states that negative social interactions play a role in depression by stressors. Therefore, negative social interactions are related to individual personalities, stressors, and depression that can trigger suicide. In this study, there was a positive correlation of $13.2 \%$ between the social environment and mental health. This means that the better the social environment, the better the nurses' mental health at the IGD Royal Prima Medan Hospital.

\section{The relationship between work environment and mental health}

Mental health in the workplace is often neglected, which has long been recognized if workers' mental health is a determinant of long-term effectiveness for organizations. Mental health can impact the company's quality while trying to achieve the desired goals. ${ }^{18}$

Fridayanti's research shows a significant effect of workplace well-being on employee mental health. Fridayanti 
researched groups with disabilities who work in companies. ${ }^{19}$ Hayati also examines mental health in the work environment. The results show that age, education, and gender mean that female employees are more susceptible to stress. According to Hayati, stress triggers are aspects of responsibility and career development. $^{20}$ In this study, the work environment is represented by years of service, career development, roles at work, and relationships with colleagues. Based on this research, the work environment is proven to have a relationship with mental health by contributing $49,8 \%$ related to emergency room nurses' mental health at Royal Prima Medan Hospital. This means that most nurses feel that high or low mental health is due to work environment factors. The higher or better the work environment, the higher the mental health of the respondent.

\section{CONCLUSION}

It can be concluded that environment, family, social environment, and work environment correlate with mental health in emergency room nurses at Royal Prima Medan Hospital during the COVID19 period. Also, demographic factors, including age, sex, and years of service, positively correlate with mental health. It can be seen from the level of significance that female nurses are more prone to mental health. The higher the age and tenure, the better the nurses' mental health at Royal Prima Hospital.

This study has several limitations that affect the results of the study. These limitations include The sample in this study is relatively small, Many research questions and The high workload of the emergency room nurses, and the emergency room's busyness, allowing respondents to answer hastily and unfocused. Future research is expected to obtain more samples so that the data can be quantitatively significant and examine other factors related to mental health.

\section{REFERENCES}
1. Ambarwati FR. Concept of Need Basic Human. Yogyakarta: Pranama Science; 2014.

2. Bakhtiar, Asriani. Strategy Effectiveness Problem-Focused Coping and EmotionFocused coping in improving Student Stress Management in public high schools 1 Barru. Guidena / Journal of Educational Sciences,Psychology, Guidance and Counseling. 2015;5(2).

3. Cag Y, Erdem H, Gormez A, Ankarali H, Hargreaves S, Ferreira-Coimbra J, dkk. Anxiety among front-line health-care workers supporting patients with COVID19: A global survey. General hospital psychiatry. 2021;68:90-96.

4. Galderisi S, Heinz A, Kastrup M, Beezhold J, Sartorius N. Toward a new definition of mental health. World Psychiatry. 2015;14(2).

5. Ghazali I. Application AnalysisMultivariate with the SPSS Program. 4 ed. Semarang: Publishing Agency Diponegoro University; 2006.

6. Giorgi G, Lecca LI, Alessio F, Finstad GL, Bondanini G, Lulli LG, dkk. COVID-19related mental health effects in the workplace: a narrative review. International journal of environmental research and public health. 2020;17(21):7857.

7. Hartono J. Research MethodsBusiness. 6 ed. Yogyakarta: Gadjah Mada University; 2014.

8. Hassanzadeh A, Heidari Z, Feizi A, Hassanzadeh Keshteli A, Roohafza H, Afshar H, dkk. Association of stressful life events with psychological problems: a largescale community-based study using grouped outcomes latent factor regression with latent predictors. Computational and mathematical methods in medicine. 2017;2017.

9. Sugiyono S. Metode penelitian kuantitatif dan kualitatif dan R\&D. Alfabeta Bandung; 2010.

10. Organization WH. International Labour Organization: Occupational safety and health in public health emergencies: A manual for protecting health workers and responders [Internet]. Organization. Organization, Geneva. 2018;

11. Bariyyah K. The effectiveness of peerhelping to reduce academic-stress of students. Addictive Disorders \& Their Treatment. 2015;14(4):176-181.

12. Manullang C, Ranimpi Y, Pilakoannu R. Mental Health and Strategy Coping in a Cultural Perspective: A Sociodemographic Study in Aminweri Village. Salatiga: Christian University Satya Wacana; 2020. 
13. Munandar A. Industrial Psychology and Organization. Jakarta: University Indonesia (UI-Press); 2011.

14. Biological. Mental Health of Employees at Work environment. A study in the Corporate Support Division Multinational. JP3SDM. 2019;8(2).

15. Du W, Zhou J, Liu J, Yang X, Wang H, He M, dkk. Social-Demographic Correlates of the Mental Health Conditions among the Chinese Elderly. Sustainability. 2019;11(24):7114.

16. Cooper CL, Davidson M. Sources of stress at work and their relation to stressors in nonworking environments. Psychological factors at work and their relation to health. 1987;99-123.

17. Murray SS, McKinney ES. Foundations of maternal-newborn and women's health nursing-e-book. Elsevier Health Sciences; 2014.

18. OECD. Expert Meeting Mental Health, Disability and Work. Paris; 2010.

19. Fridayanti F, Kardinah N, Fitri TJN. Peran Workplace Well-being terhadap Mental Health: Studi pada Karyawan Disabilitas. Psympathic: Jurnal Ilmiah Psikologi. 2019;6(2):191-200.

20. Hayati Y, Movahed E, Arab M. Assessing the status of managers' leadership style and its relationship with mental health staff of hospitals affiliated to Tehran University of Medical Sciences in 2014. Journal of Hospital. 2017;16(1):55-62. 